\title{
BELAJAR (Bekal Antar Pelajar): Service Built by Mobile Application for Full Day School Program Students
}

\author{
Silvia Arina Hidayati \\ Department of Elementary School Teacher Education \\ State University of Malang, Indonesia \\ silvia.arinahidayah@gmail.com \\ Ryandini Dwi Puspita \\ Department of Elementary School Teacher Education \\ State University of Malang, Indonesia \\ ryandinipuspita1@gmail.com
}

\author{
Rezha Anggi Rinensi \\ Department of Elementary School Teacher Education \\ State University of Malang, Indonesia \\ rezhaanggi07@gmail.com \\ Indra Gunawan \\ Department of Informatics Engineering \\ State University of Malang, Indonesia \\ gun.indra04@gmail.com
}

\author{
Uswatun Khasanah \\ Department of Management \\ State University of Malang, Indonesia \\ uswakhasann@gmail.com
}

\begin{abstract}
One of the programs has been implemented by the Ministry of Education and Culture Indonesia is Full Day School. the polemical problem caused by the occurrence of lunch hour is usually done at home, so the child's diet becomes irregular and unhealthy which of course makes their health disturbed. Meanwhile, not all parents have spare time to prepare supplies and send food to school. Therefore PKM-K is made so that parents can control children's lunch. There is also an outcome target that is Application "BELAJAR" that is provision of food service providers based on mobile application. So it can support the full day school program to run well. The implementation methods used include aspects of management, finance, marketing, location and business, as well as the implementation of activities ranging from preproduction, production to marketing. The results include the completion of the application that will be used with features that facilitate ordering, provisions produced that have a uniqueness that can attract consumers, testimonials provided by elementary school students, consultation with a professional nutrition expert in the field, and consultation with the parties the education office related to the full day school program that has been implemented.
\end{abstract}

Keywords: food supply service provider, mobile application, full day school

\section{INTRODUCTION}

The vision of the Jokowi-Jusuf Kalla government has been formulated in the Nawacita, which has three main features of the State present, the Build from the periphery, and the mental Revolution (Kominfo, 2016). Of the nine programs of the Nawacita, at the eighth point mentioned that to revolutionize the character of the nation through the policy of rearranging the national education curriculum by promoting the aspect of civic education, which puts proportional aspects of education, such as the teaching of the history of nation formation, patriotism values and homeland love, the spirit of defending the state and manners in the education curriculum of Indonesia.

One of the programs that has been implemented by the government is Full Day School. Where, full day school itself is a public school model that integrates intensive character teaching system by providing additional time for the deepening of religious students. Usually the additional hours are allocated to the hours after the prayer dhuhur until ashar prayer, so practical school model is entered at $07.00 \mathrm{pm}$ back at $16.00 \mathrm{pm}$ (Sismanto, 2007). It is based on Ministerial Regulation No. 23 / 2017 on Full Day School.

\section{METHODS}

\section{A. Management Aspects}

Steps taken to simplify and streamline the management process, then first made the organizational structure. Similarly, the description of each section in accordance with the ability to perform the task, thus each member of the group of Entrepreneurship PKM can work optimally and professionally.

Members have a field that is qualified in the world of education, especially the scope of primary school and create interactive media (Table 1). Creation of applications by Informatics Engineering students who are experts in the field of application design. As well as members of the economy as financial analysis and implementers to create programs in the field of marketing to increase sales.

\section{B. Financial Aspect}

As an illustration of the feasibility of production of Learning stock, the following is the sales of 400 boxes in a month, with details of 100 boxes per package (20 boxes per day). Production of supplies requires working capital of Rp 8.000.000,- with the following calculations (Table 2). 
Table 1

Member and Job Description

\begin{tabular}{|l|l|}
\hline \multicolumn{1}{|c|}{ Name } & \multicolumn{1}{c|}{ Job Description } \\
\hline Silvia Arina Hidayati & Coordinate and take responsibility for all activities \\
\hline Ryandini Dwi Puspita & Record orders according to the application's database \\
\hline Rezha Anggi Rinensi & Coordinate food reservations and monitor the production process of catering \\
\hline Indra Gunawan & The designer of the application and monitor the courier work \\
\hline Uswatun Khasanah & Recording of all budgets and marketing strategists \\
\hline
\end{tabular}

Table 2

Break Even Point (BEP)

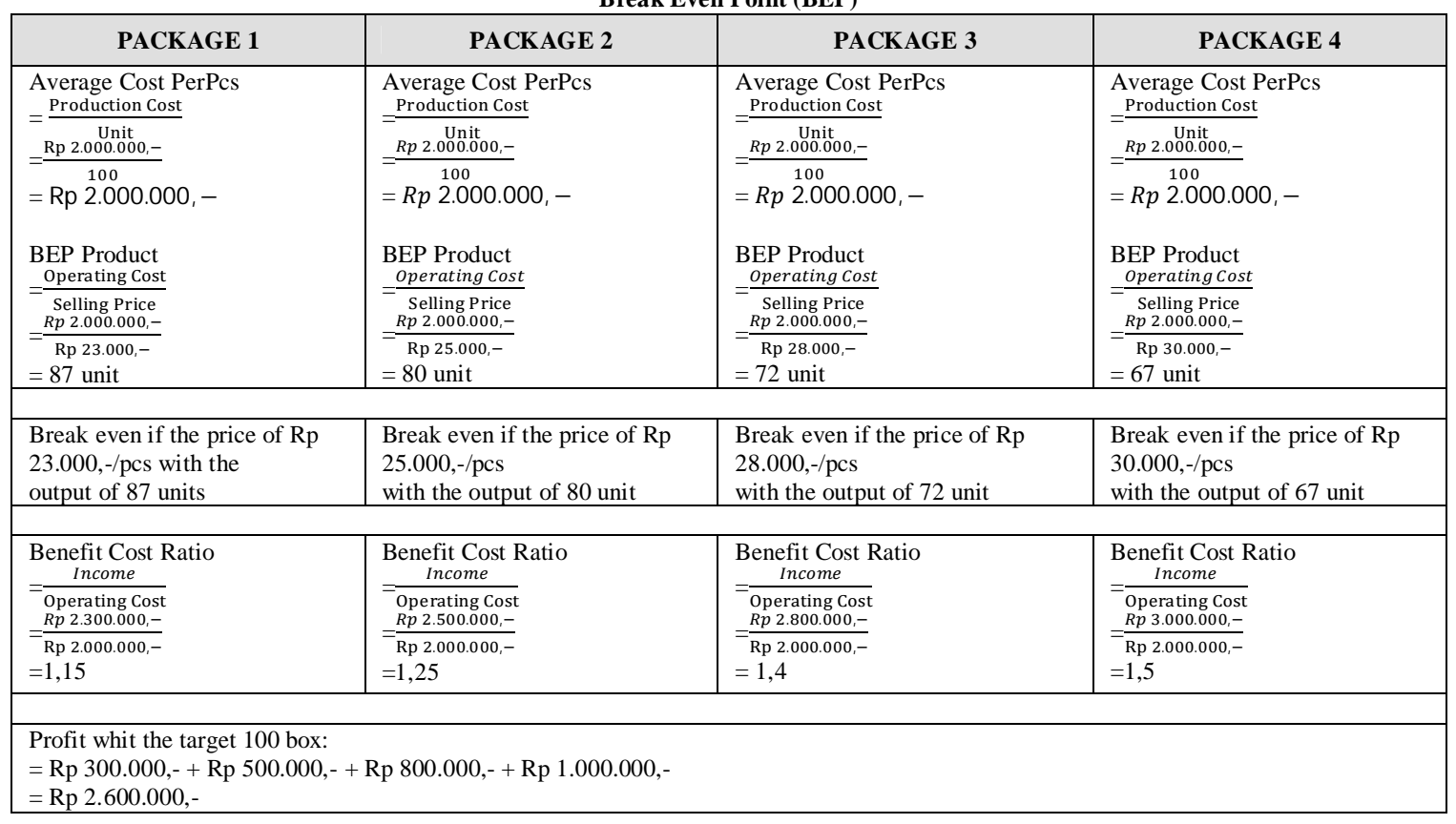

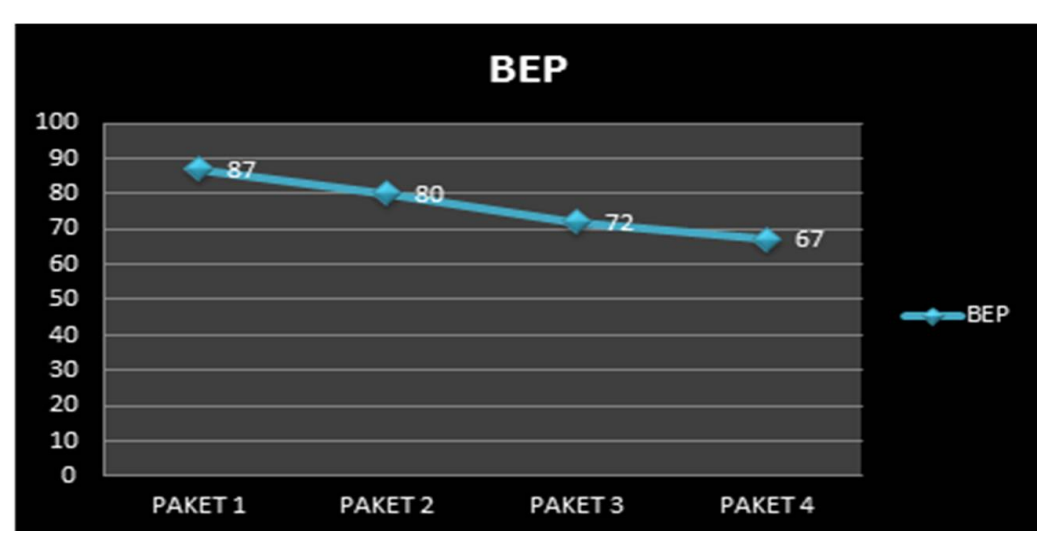

Figure 1

Break Even Point (BEP) Chart

Table 2

Profit Calculation for 1 Month

\begin{tabular}{|c|c|c|c|c|c|}
\hline Package & Price & BEP & Amount & $\begin{array}{c}\text { Target } \\
\text { (100 Box / Month) }\end{array}$ & Profit \\
\hline PACKAGE 1 & $\operatorname{Rp} 23.000,-$ & 87 Box & Rp 2.000.000,- & Rp 2.300.000,- & Rp 300.000,- \\
\hline PACKAGE 2 & $\operatorname{Rp} 25.000,-$ & 80 Box & $\operatorname{Rp} 2.000 .000,-$ & $\operatorname{Rp} 2.500 .000,-$ & $\operatorname{Rp} 500.000,-$ \\
\hline PACKAGE 3 & $\operatorname{Rp} 28.000,-$ & 72 Box & $\operatorname{Rp} 2.000 .000,-$ & $\operatorname{Rp} 2.800 .000,-$ & $\operatorname{Rp} 800.000,-$ \\
\hline PACKAGE 4 & Rp 30.000,- & 67 Box & $\operatorname{Rp} 2.000 .000,-$ & Rp 3.000.000,- & Rp 1.000.000,- \\
\hline
\end{tabular}


Criteria B / C Ratio if > 0 then said to profit, and if B / C Ration < 0 then said loss while if B / C Ratio $=0$ then the business is even (Figure 2). From the results $\mathrm{B} / \mathrm{C}$ interest is all packets above 0 then it can be said that this business is worth continuing.

\section{Payback Period:}

$=($ Total Investment $\mathrm{x}$ Period $) /$ Profit

$=(\operatorname{Rp~8,000,000\times 1~month}) /(\operatorname{Rp} 2.600 .000)$

$=3.1$ months (capital will return after 3.1 months)

\section{Marketing Aspects}

The marketing of products stocked with applications BELAJAR will be done with two marketing strategies that are direct selling and indirect selling. Direct selling promotes by offering directly to several elementary schools that apply full day school program in unlucky area, doing word of mouth strategy, and joining race events, while for selling indirect selling through instagram and website promotion.

\section{Location and Business Management Aspects}

Enterprises service provision of food provision based on mobile application is owned by 5 people as joint business owners, by creating a $\mathrm{CV}$ Belajar. Everyone monitors and carries out all production activities, transactions, and promotions on the market. Management is governed by business owners from capital, pricing, production costs and others.

The form of a business entity belonging to a business group with capital derived from Ristekdikti. In addition, determining the business center in Malang because it is close to the target of the elementary schools that have implemented the program Full Day School, so it has a large market potential. In addition, business owners are also domiciled in the city of Malang.

\section{E. Activity Implementation Aspect}

1. Pre-Production Stage

At the pre-production stage the activities are aimed at finalizing any concept of the product to be made, including: (a) research on schools that have implemented Full Day School programs; (b) surveys with catering partners, couriers and consultations with nutritionists; (c) targeting and segmentation; and (d) handling letters of recommendation to faculty, bakesbanpol, and research to Malang Education Office.

\section{Production Stage}

In the production stage, the activity is aimed to carry out the preparation of the provision according to the segmentation and the target of the fulfillment of the consumers' needs, among others: (a) the production of supplies in accordance with the demand for the package; (b) the confirmation to the catering; (c) the delivery process to the school courier; and (d) confirm delivery settlement by courier and consumer.

\section{Marketing Stage}

At the marketing stage of the activity, it is aimed to carry out the sales with the strategies taken in accordance with the segmentation and the target market, the steps taken such as: (a) promotion in social media; (b) cooperation with the school and parents; (c) participating in race and olympic events; and (d) evaluation and report generation.

\section{RESULT}

Figure 2 Application display "BELAJAR" (supply between students) Mobile Application Provider Service Based Mobile Application For Students Full Day School Program is designed with an attractive and adorable logo tailored to the sales target. This application also has some features that aims to facilitate ordering, so that the buyer does not have difficulty in understanding the features that have been provided.

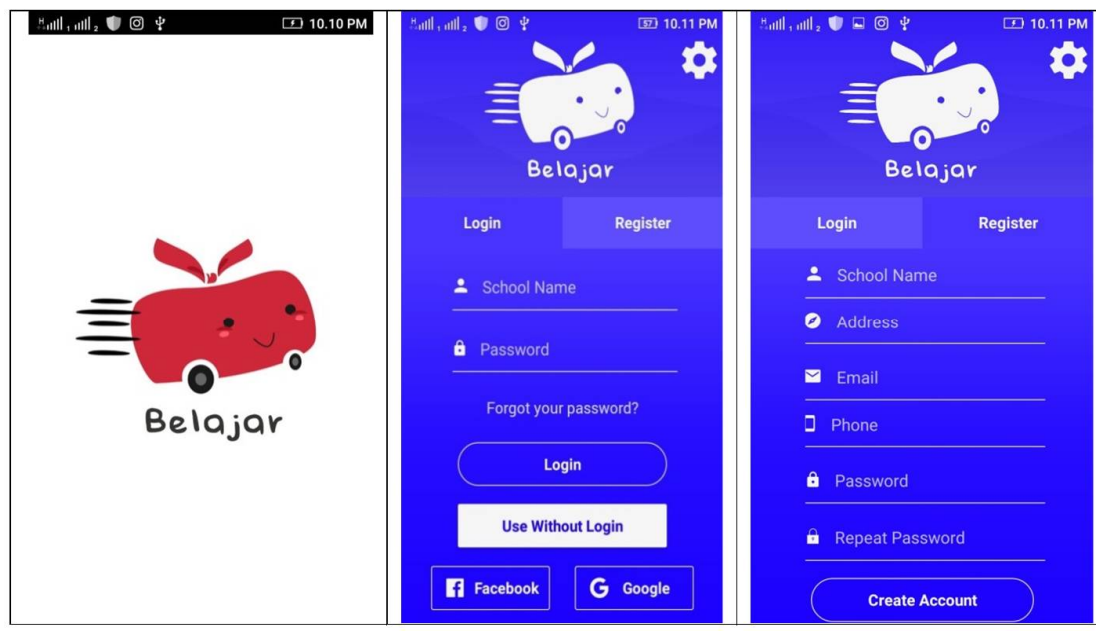

Figure 2

Application Display "BELAJAR" 
Figure 3 display supplies that have been in production and ready to be delivered to the consumer, and ready to accompany the children in full learning Full Day School. The funny look can increase the child's appetite, and parents should not worry about the food consumed by the child. Figure 4 Photo testimony from consumers when they have received a packet of supplies using the application "BELAJAR".

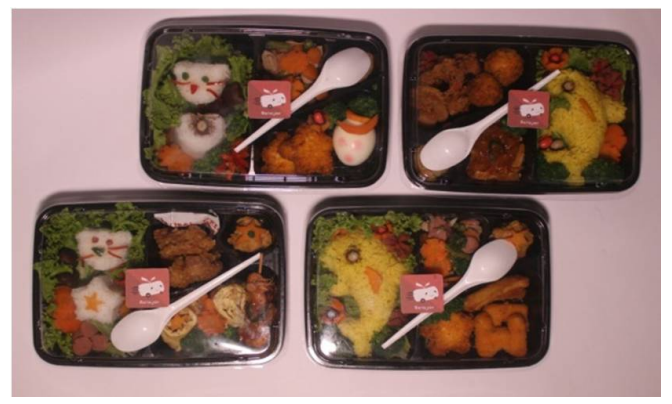

Figure 3

Display Supplies

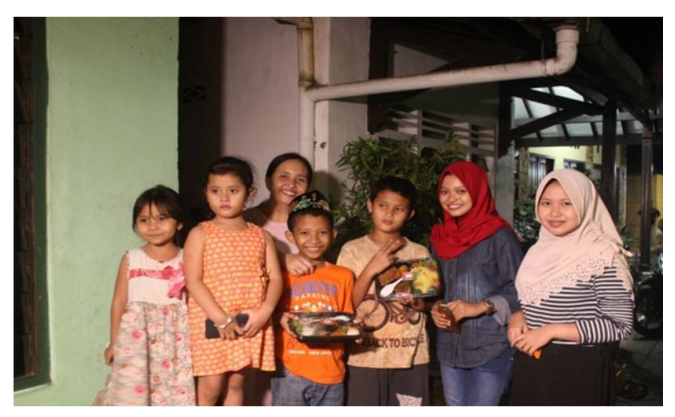

Figure 4

Photo Testimony from Consumers

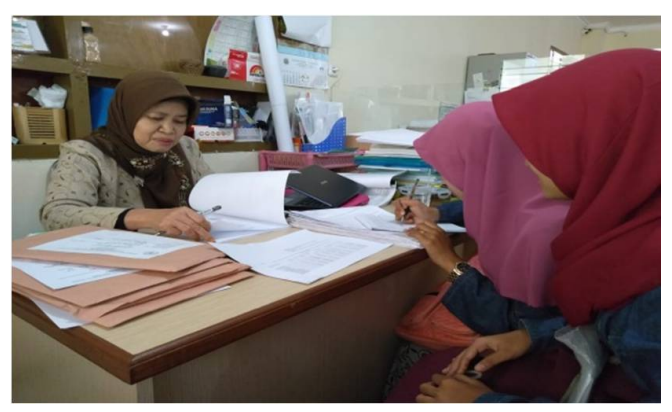

Figure 5

Previously Manufactured Supplies

Figure 5. Previously manufactured supplies have been consulted with Dra's mother. Nunung Nurjanah, M.Kes who works as a nutritionist is also a lecturer in the department of engineering department of industrial engineering State University of Malang, so he can be sure he is a professional in his field.

\section{DISCUSSION}

Among these statements, the polemical problems that occur are it was the usual lunch hour at home. It makes the child's diet becomes irregular and unhealthy which of course makes their health disturbed. Meanwhile, not all parents have spare time to prepare supplies and send food to school. especially the carier parents who only have limited time to prepare or just send food to their children.

In fact, to achieve the goal of full day school is needed a variety of support, including good nutrition status of students. Adequate nutrition greatly affects the intelligence and productivity of human labor. Aspects that affect the nutritional status include aspects of food patterns, socio-cultural and the effects of food consumption (Suhardjo, 2003; Kusmintardjo and Gunawan, 2017).

Foods consumed by students at lunch time include many yaitubah containing dyes, preservatives, artificial sweeteners, flavorings. The food is obtained from the school cafeteria that has not shown the feasibility of the canteen as a healthy canteen. In addition to outdoor snacks also still create a special attraction for students who are hungry.

In addition to its cheap price, it tastes good, and the color is interesting to make students prefer the snack. From the above problems, the foundation to create a solution in support of the success of the program nawacita, especially Full Day School.

The development of communication technology, such as smartphones that are currently owned by many people in various circles, provide convenience especially for parents. The app product "BELAJAR" is one the solution. Applications "BELAJAR" based on android.

Features available at in the application is easy to operate so ordering can be easier, efficient, as well as the affordable price and the corresponding quality compared with outdoor snacks that have not guaranteed health and hygiene. "BELAJAR" application helps confused parents to divide their time to meet their children's lunch with healthy, nutritious (4 healthy 5 perfect) meals, interesting, delicious, and of course quality guaranteed.

\section{CONCLUSION}

Nawacita Program at the eighth point mentioned that the nation character revolution through the policy of rearranging the national education curriculum. One of the programs that has been implemented by the government is Full Day School. Various problems arise, one of which is the reduction of lunch hour and parents who are busy with a career so they do not have time to monitor what is in the consumption of children.

So the solution of these problems is Product Application "BELAJAR". Applications "BELAJAR" based on android. The features available in the application are easy to operate so the ordering can be more easily, efficiently, and the price is affordable and the quality is suitable compared to the outside snacks that are not guaranteed health and hygiene. After analysis of management aspect, financial aspect, 
marketing aspect, location aspect and business management, and implementation aspect of the activity, it can be seen that PKM K is very feasible to be developed because it has good prospect in the future.

\section{ACKNOWLEDGMENTS}

Acknowledgments to the Ministry of Research, Technology and Education Height that has provided funding to the implementation of the PKMEntrepreneurship app BELAJAR.

\section{REFERENCES}

[1] Akbar, S. D. 2007. Pembelajaran Nilai Kewirausahaan dalam Perspektif Pendidikan Umum: Prinsip-prinsip dan Vektor-vektor Percepatan Proses Internalisasi Nilai Kewirausahaan. Malang: State University of Malang.

[2] Akbar, S. D. 2016. Optimalisasi Peran Sekolah dalam Membangun Karakter. Paper Presented National Seminar: Optimalisasi Peran Keluarga dan Sekolah dalam Pembangunan Karakter Anak, Faculty of Economy, State University of Malang.

[3] Frediyatma, S. Y. 2014. Aplikasi Pemesanan Makanan Berbasis Cloud dengan Platform Android. Jurnal Ilmiah Merpati (Menara Penelitian Akademika Teknologi Informasi), 5(1), 1-14.

[4] Irwansyah, E. 2013. Sistem Informasi Geografis: Prinsip Dasar dan Pengembangan Aplikasi. Yogyakarta: DigiBook.

[5] Kusmintardjo, \& Gunawan, I. 2017. Manajemen Layanan Khusus. Malang: Universitas Negeri Malang, UM Press.

[6] Kusuma, M. W. W. 2016. Perancangan dan Implementasi Pemesanan Makanan dengan Memanfaatkan Teknologi JSON dan Base 64: Studi Kasus Bakmi Hapkie Semarang. Dissertation. Salatiga: UKSW.

[7] Ministry of Education and Culture. 2017. Summary of 2016/2017 Primary and Secondary Education Statistics. Jakarta: Kemendikbud.

[8] Rahmasari, P. 2015. Pengembangan Media Segitiga Pintar pada Pembelajaran Tematik Tema Makananku Sehat dan Bergizi Kelas IV Sekolah Dasar. Dissertation. Malang: University of Muhammadiyah Malang.Rina, P, L. 2016. Pembelajaran Pengenalan Makanan Bergizi pada Anak Kelompok A di TK LKIA 2 Pontianak Selatan. Jurnal Pendidikan dan Pembelajaran, 5(7).

[9] Suharjo. 2003. Nutrition and Food. Yogyakarta Kanisius.

[10] Syafrizal, D. 2017. Sistem Informasi Order Makanan dan Booking Tempat Berbasis Mobile Android Menggunakan Protokol JSON. Dissertation. Palembang: UIN Raden Fatah Palembang. 